\title{
ATTACHMENT REACTION OF THE UTERINE LUMINAL EPITHELIUM AT IMPLANTATION: LIGHT AND ELECTRON MICROSCOPY OF THE HAMSTER, GUINEA-PIG, RABBIT AND MINK
}

\author{
K. HEDLUND, O. NILSSON, S. REINIUS AND G. AMAN \\ Institute of Human Anatomy, S752 20 Uppsala, and \\ Agricultural College, S 75007 Uppsala, Sweden
}

(Received 26th October 1971, accepted 4th November 1971)

Close apposition of the mucous surfaces-the attachment reaction-occurs on implantation in the mouse (Potts, 1966, 1968; Nilsson, 1967; Reinius, 1967; Potts \& Psychoyos, 1967b) and the rat (Mayer, Nilsson \& Reinius, 1967; Nilsson, 1967; Potts \& Psychoyos, 1967a). Since both these species have an eccentric implantation, it seemed possible that the occurrence of the attachment reaction might be correlated with the type of implantation. The ultrastructure of the uterine surface epithelium was therefore examined at preimplantation and implantation in animals representative for different modes of implantation - eccentric (the hamster), central (the rabbit and the mink) and interstitial (the guinea-pig).

The animals were bred under standardized conditions. Mating of the animals was verified in the hamster and guinea-pig by the presence of vaginal spermatozoa (Day 1 of pregnancy) and in the rabbit and the mink by controlled mating.

The preimplantation and implantation stages were obtained from the hamster on Day 4 (three animals) and Day 6 (four animals), from the guinea-pig on Day 4 (three animals) and Days 7 to 8 (four animals), from the rabbit 4 to 5 days (three animals) and 10 days (six animals) after mating, and from the mink 6 days (three animals) and 12 to 14 days (five animals) after double mating according to Hansson (1947).

Fixation was performed by an aortic perfusion with $2.5 \%$ glutaraldehyde in Sørensen's phosphate buffer at $\mathrm{pH} 7 \cdot 4$. The uterine horns were carefully dissected free, and specimens from the middle third of the horns were post-fixed in $1 \%$ osmium tetroxide in Sørensen's phosphate buffer, $\mathrm{pH} 7 \cdot 4$. The specimens were embedded in Epon. Sections for light microscopy were stained with toluidine blue and for electron microscopy with uranyl acetate followed by lead citrate.

At preimplantation, the sections of uteri from the hamster, the guinea-pig, the rabbit and the mink showed wide luminal spaces and regular micro-villi on the luminal surfaces. At implantation, however, the appearance of the luminal regions varied among the species. The attachment reaction of the uterine epithelium occurred in the hamster (P1. 1, Fig. 1) and the guinea-pig (Pl. 1, Fig. 2), but not in the rabbit (Pl. 1, Fig. 3) or the mink. 
The attachment reaction, therefore, has been observed in association with eccentric implantation in the rat, mouse and hamster, and with interstitial implantation in the guinea-pig but not in association with central implantation in the rabbit and mink. Man and monkey also have an interstitial implantation, but the ultrastructure of human endometrial biopsies (Cavazos, Green, Hall \& Lucas, 1967; Wynn \& Woolley, 1967) and perfusion experiments of the rhesus uterus (Reinius \& Knobil, 1972) point to an absence of this reaction. Therefore, at least among the species with interstitial implantation, the occurrence of the attachment reaction varies and, thus, it cannot be correlated to the types of implantation mentioned.

The attachment reaction should favour implantation by endometrial 'grasping' of the blastocyst, which by this means becomes pressed onto the uterine surface. In the species (rabbit and mink) with central implantation where the phenomenon is lacking, it can be assumed that the expansion of their blastocysts produces a similar effect (Daniel, 1964). It is not yet known whether and, if so, how the primate blastocyst compensates for the apparent lack of both the attachment reaction and blastocyst expansion (Bregulla, 1969).

The Swedish Medical Research Council (Project Nr B70-12X-70) contributed towards the cost of this study.

\section{REFERENGES}

Bregulla, K. (1969) Das menschliche Ei, Wachstum, Reifung, Ernährung und Befruchtung. Die Manipulation mit dem Ei. Arch. Gynaek. 208, 57.

Cavazos, F., Green, J. A., Hall, D. G. \& Lucas, F. V. (1967) Ultrastructure of the human endometrial glandular cell during the menstrual cycle Am. F. Obstet. Gynec. 99, 833.

Daniel, J. C., JR (1964) Early growth of rabbit trophoblast. Am. Nat. 98, 85.

Hannsson, A. (1947) The physiology.of reproduction in mink (Mustela vison Shreb.) with special reference to delayed implantation. Acta zool., Stockh. 28, 1.

Mayer, G., Nilsson, O. \& Reinius, S. (1967) Cell membrane changes of uterine epithelium and trophoblasts during blastocyst attachment in rat. Z. Anat. EntwGesch. 126, 43.

NiLsson, O. (1967) Attachment of rat and mouse blastocysts onto uterine epithelium. Int. F. Fert. 12, 5.

Potrs, D. M. (1966) The attachment phase of ovo implantation. Am. F. Obstet. Gynec. 96, 1122.

PotTs, D. M. (1968) The ultrastructure of implantation in the mouse. F. Anat. 103, 77.

Potтs, D. M. \& Psychoyos, A. (1967a) Evolution de l'ultrastructure des relations ovoendométriales sous l'influence de l'oestrogène, chez la ratte en retard expérimental de nidation. C.r. hebd. Séanc. Acad. Sci., Paris, 264, 370.

Potrs, D. M. \& Psychoyos, A. (1967b) L'ultrastructure des relations ovoendométriales au cours du retard expérimental de nidation chez la souris. C.r. hebd. Séanc. Acad. Sci., Paris, 264, 956.

Reinius, S. (1967) Ultrastructure of blastocyst attachment in mouse. Z. Zellforsch. mikrosk. Anat. 77, 257.

Reinius, S. \& KNoBIL, E. (1972) Electron microscopy of an early implantation in the rhesus monkey. F. Reprod. Fert. (In press).

WYNN, R. M. \& WoolLex, R. S. (1967) Ultrastructural cyclic changes in the human endometrium. II. Normal postovulatory phase. Fert. Steril. 18, 721.

\section{EXPLANATION OF PLATE 1}

Fig. 1. Hamster, implantation. The uterine lumen has disappeared, and apposing surfaces of the uterine epithelium form a close contact (the attachment reaction of the uterine epithelium). $\times 21,000$.

FIG. 2. Guinea-pig, implantation. Luminal surfaces of the epithelium show the attachment reaction. $\times 14,000$.

FIG. 3. Rabbit, implantation. Apposing luminal surfaces of the epithelium are separated by a luminal space and possess microvilli. $\times 2500$. 
PLATF 1
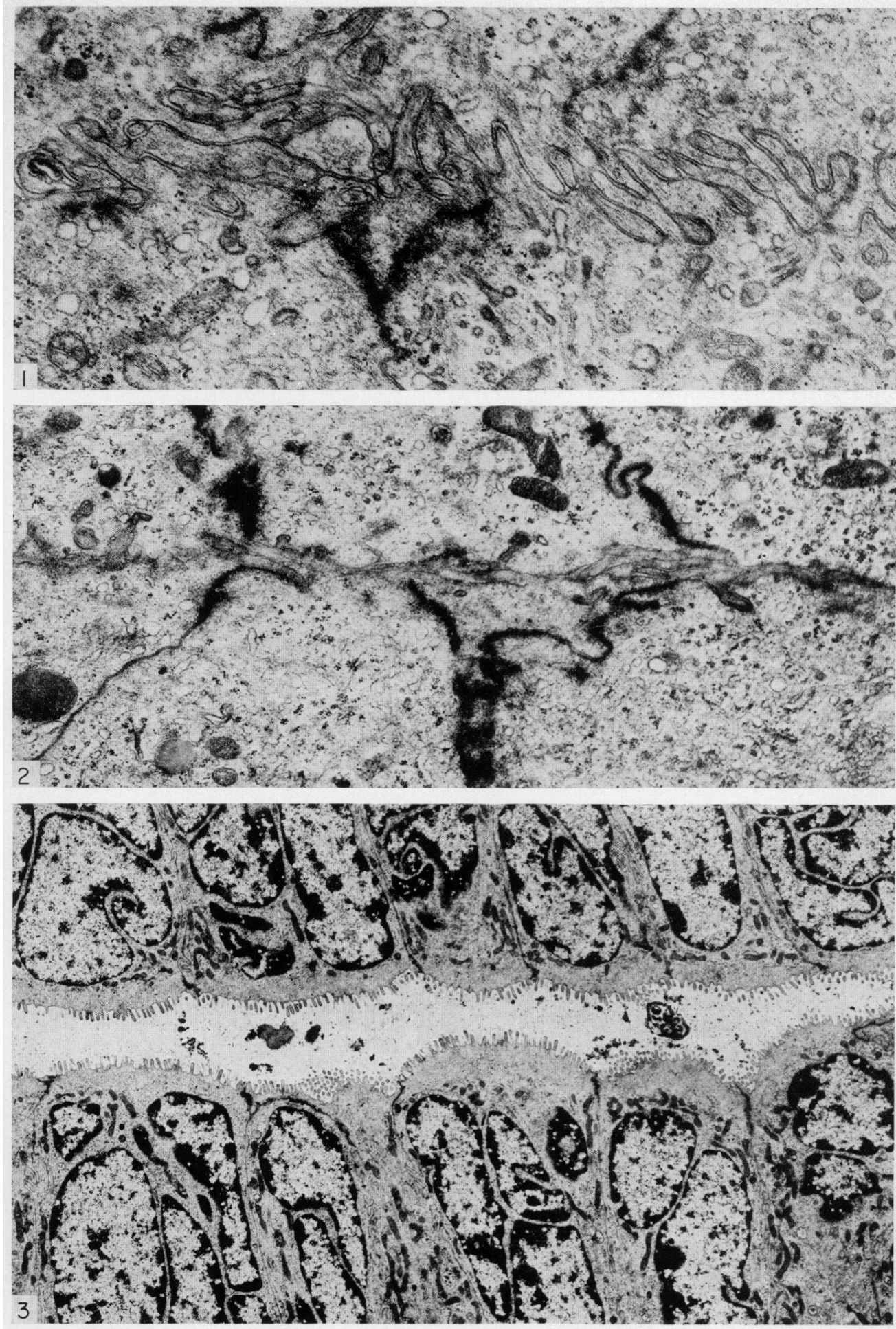

(Fuing p. 132) 